Editorial

\title{
The Impact of Media on Traditional Communities
}

\author{
Raul Reis \\ School of Journalism and Mass Communication, Florida International University, Miami, FL, 33199, USA; \\ E-Mail: reisr@me.com
}

Submitted: 15 April 2016 | Published: 26 April 2016

\begin{abstract}
This editorial provides a brief historical overview of research on the impact of media on traditional communities, and introduces the articles featured in this issue.
\end{abstract}

\author{
Keywords \\ ethnography; indigenous communities; media impact; social media
}

Issue

This editorial is part of the issue "The Impact of Media on Traditional Communities", edited by Raul Reis (Florida International University, USA).

(C) 2016 by the author; licensee Cogitatio (Lisbon, Portugal). This article is licensed under a Creative Commons Attribution 4.0 International License (CC BY).

Mass media globalization is a phenomenon almost as old as mass communication itself, starting in the beginning of the $20^{\text {th }}$ century as movies, radio shows and later television programs became profitable cultural products, easily exportable to international audiences. It accelerated in the 1980s and 1990s, as technological advances such as satellite telecommunications became a reality, allowing audiences to share those cultural artifacts in real time. The Internet and social media further demolished all geographical and chronological barriers, allowing even the most distant and isolated communities to share globalized media experiences (as long as they have access to electricity, connectivity, and the proper hardware, which is by no means guaranteed, even as those become cheaper and more widespread.)

Interest in the effect that mass media exposure has on traditional communities also started almost as soon as mass media itself became an international phenomenon. It soon became apparent to anthropologists, sociologists, and fledging mass communication researchers that exposure to mass media was, at a minimum, influencing (if not disrupting) traditional ways of life. What followed in the 1970s, 1980s and 1990s was a flurry of Frankfurt School-inspired studies that mainly focused on the negative aspects of that influence. Terms such as cultural imperialism and cultural hegemony were widely used to define that process, as re- searchers worried that ancient traditions and ways of life were seriously threatened by the culture industry.

With the growth of cultural studies in the $1970 \mathrm{~s}$ and 1980s, the critique became much more complex and nuanced, as scholars such as James Clifford and Stuart Hall (heavily indebted to French philosophers such as Michel Foucault, Felix Guattari and Jacques Derrida) started to talk about culture as being polysemic and formed by "seriously contested codes and representations" (Clifford, 1988). The field of intercultural communication has also dissected (with varying degrees of success) the complex ways in which cultures and cultural groups come to influence each other, once they start interacting. Instead of focusing only on the negative aspects of that interaction, more recent studies have also focused on the way mass media may empower communities to seek agency and self-determination (Martín-Barbero, 1993; Reis, 1998).

As media production technology becomes cheaper and more readily available, researchers have paid more attention to how previously disenfranchised communities develop their own communication systems, using mass media not only to communicate, but also to advance their own agendas (Horst, 2011). More recently, researchers have turned their attention to the Internet, social media and micro-blogging, asking, for example, how Brazilian favela residents engage with social media, 
and if we should look at their social media engagement as another form of empowerment (Nemer, 2015).

This thematic issue of Media and Communication lands within this historical backdrop, pushing against its current disciplinary boundaries. In "Media Portrayals of Hashtag Activism: A Framing Analysis of Canada's \#ldleNoMore Movement," Derek Moscato examines the confluence of activism and social media, using framing theory to analyze how two prominent Canadian publications portrayed the \#IdleNoMore social media campaign initiated by Canada's First Nations communities. No longer at the recipient end of the traditional mass media flowchart, Aboriginal communities are turning the tables, and engaging with social media in a way that inserts their demands and concerns right in the middle of the political arena. As he discusses in his article, from Tunisia to Canada, micro-blogging has been a particularly effective way to organize and give voice to politically disenfranchised communities.

Through framing analysis, Moscato has found that the reaction to hashtag activism by traditional media has been mixed, allowing national circulation publications to highlight or give voice to indigenous demands, while at the same time admonishing against possible escalation of political confrontation.

From Canada we move south to Brazil, where Laura Graham sets her sights on the A'uwẽ-Xavante indigenous communities of Mato Gross state and their use of audio-visual technologies. What started as the communities' attempt to preserve and disseminate their own rites and ceremonies (mainly as teaching tools and historical artifacts), has evolved to allow the A'uwẽXavante peoples to exert greater control over how they are presented and represented, in a process that Graham describes as "representational sovereignty."

As a rebuke to the idea of a "Faustian contract," whereupon indigenous communities' use of modern technologies would inevitably compromise their purity, Graham argues that the A'uwẽ-Xavante's use of audiovisual technologies is one of many recent examples of indigenous communities turning self-produced cultural artifacts into "powerful instruments for the creative expression of identity, self-reflection, political empowerment, cultural transmission, and the preservation of traditional knowledge."

Finally, in a beautifully written and powerful commentary, Richard Meadows traces the history of how communication networks have been used by Australian Aboriginals for hundreds of years, pre-dating the European occupation of the continent. As European vessels moved along the Australian coastline, Aboriginal "runners" moving through inland tracks kept informed a complex maze of Aboriginal nations speaking upwards of 250 languages. As more and more Aboriginal Australians embrace community-produced radio and television, even fostering a creative national alliance, Richard Meadows decries the lack of a national Indigenous media policy, formally recognizing (and preserving) the importance of Aboriginal languages and cultures.

As we move towards a world that will make media and social media engagement as inevitable for traditional communities as breathing or eating, it is imperative that, as anthropologists and mass communication researchers, we discuss, examine and study the powerful ways in which new technologies influence those groups, including the creative (and political) ways in which those groups themselves are producing and engaging with media. The articles in this new thematic issue make an important step toward that goal.

\section{Conflict of Interests}

The author declares no conflict of interests.

\section{References}

Clifford, J. (1988). The predicament of culture: Twentieth century ethnography, literature, and art. Cambridge, MA: Harvard University Press.

Horst, H. A. (2011). Free, social, and inclusive: Appropriation and resistance of new media technologies in Brazil. International Journal of Communication, 5, 437-462.

Martín-Barbero, J. (1993). Communication, culture, and hegemony: From the media to mediations. London: Sage.

Nemer, D. (2015). Online favela: The use of social media by the marginalized in Brazil. Information Technology for Development. doi:10.1080/02681102.20 15.1011598

Reis, R. (1998). The impact of television viewing in the Brazilian Amazon. Human Organization: Journal of the Society for Applied Anthropology, 57(3), 253257.

\section{About the Author}

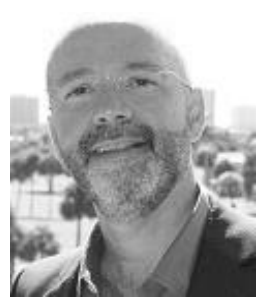

\section{Dr. Raul Reis}

Raul Reis is a tenured professor in the School of Journalism and Mass Communication (SJMC) at Florida International University (FIU) in Miami, Florida. He was the dean of the school from 2011 to 2016. Professor Reis will be the Dean of the School of Communication at Emerson College in Boston, Massachusetts, as of July 2016. 